\title{
PENGGUNAAN HANDPHONE SEBAGAI MEDIA PEMBELAJARAN \\ MELALUI APLIKASI KINE MASTER UNTUK MENINGKATKAN \\ MINAT BELAJAR IPS DI SMP NEGERI 2 BANYUASIN III
}

\author{
Elli Iryani, S.Pd., M.Si. \\ SMP Negeri 2 Banyuasin III \\ elliiryani0505@gmail.com
}

\begin{abstract}
ABSTRAK
Penggunaan media pembelajaran yang tepat akan meningkatkan kualitas pembelajaran di sekolah. Penggunaan media pembelajaran yang mudah di dapat dan hampir sebagian besar dimilki oleh peserta didik adalah Handphone, di mana handphone merupakan alat komunikasi yang menjadi bagian yang tidak terpisahkan dari kehidupan anak-anak muda pada era millennial sekarang ini. Penggunaan media pembelajaran dengan aplikasi kine master bertujuan untuk memperbaiki proses pembelajaran dengan memanfaatkan alat peraga dan media teknologi komunikasi yang mudah didapat dan dimiliki oleh sebagian besar peserta didik. Penelitian ini menggunakan penelitian tindakan karena penelitian tindakan kelas merupakan penelitian yang lebih sesuai dengan tugas pokok dan fungsi guru, meningkatkan kualitas pembelajaran, meningkatkan kualitas siswa, serta mencapai tujuan pembelajaran atau pendidikan. Penelitian Tindakan Kelas (PTK) atau Classroom Action Research merupakan bentuk kajian yang bersifat reflektif oleh pelaku tindakan, dilakukan untuk meningkatkan kematangan rasional dari tindakan dalam melakukan tugas, memperdalam pemahaman terhadap tindakan yang dilakukan serta memperbaiki kondisi tempat praktek pembelajaran tersebut dilakukan. Pada penelitian siklus I nilai rerata yang didapat siswa adalah 73,50 dan pada penelitian siklus II nilai rerata sudah mencapai 82,50 , hal ini berarti setelah pembelajaran IPS dengan materi materi organisasi pergerakan dan tumbuhnya semangat kebangsaan menggunakan media handphone terjadi peningkatan minat belajar siswa. Hasil penelitian menunjukkan bahwa dengan menggunakan handphone dengan aplikasi kine master kegiatan pembelajaran tentang organisasi pergerakan dan tumbuhnya semangat kebangsaan berlangsung secara aktif, kreatif, menyenangkan, dapat meningkatkan minat belajar peserta didik pada pelajaran IPS dan meningkatkan prestasi belajar peserta didik.
\end{abstract}

Kata Kunci : Aplikasi Kine Master, Handphone, Minat Belajar Siswa

\begin{abstract}
The use of appropriate learning media will improve the quality of learning in schools. The use of learning media that is easy to obtain and almost partly owned by students are a Handphone, which is the handphones are a communication tool
\end{abstract}


PENGGUNAAN HANDPHONE SEBAGAI MEDIA PEMBELAJARAN MELALUI

APLIKASI KINE MASTER UNTUK MENINGKATKAN MINAT BELAJAR IPS DI SMP

NEGERI 2 BANYUAS IN III

(Elli Iryani, S.Pd., M.Si.)

that is become a part of a young people and it can't separates from a part of this millennial life. The use of learning media with a Kine master application is purpose to improve a learning process by make use of demonstration props and communication technology media that are easy to obtained and owned by most of students. This research is using a classroom action research because a classroom action research is more suitable with the main duties and the functions of teacher, improving the quality of learning, improving the quality of students, and it can achives the learning goals or the education. The classroom action research is a form of study that tends to be reflective by the actor of action, carried out to improve the rational maturity of the action in performing tasks. In the first cycle research the average value that obtained by students was 73,50 and In the second cycle research the average value had reached 82,59, It means after learning social sciences with the materials movements organization and growing the spirit of nationality by using handphones, there is an increase in students interest of learning. The results of this study indicate that by using handphones with The Kine Master application the learning activities of movements organization And the growing sprit of nationality occur to be actively, creative, fun and it can increases the students interest of learning Social Science lesson and it can improve the students achievement.

\section{Keywords : Kine Master Application, Handphones, Students Interest}

\section{PENDAHULUAN}

\section{A. Latar Belakang}

Ilmu Pengetahuan Sosial (IPS) merupakan salah satu mata pelajaran yang diberikan mulai dari SD/MI/SDLB sampai SMP/MTs/SMPLB. IPS mengkaji seperangkat peristiwa, fakta, konsep, dan generalisasi yang berkaitan dengan isu sosial. Pada jenjang SMP/MTs mata pelajaran IPS memuat materi Geografi, Sejarah, Sosiologi, dan Ekonomi. Melalui mata pelajaran IPS, peserta didik diarahkan untuk dapat menjadi warga negara Indonesia yang demokratis, dan bertanggung jawab, serta warga dunia yang cinta damai. Di masa yang akan datang peserta didik akan menghadapi tantangan berat karena kehidupan masyarakat global selalu mengalami perubahan setiap saat. Oleh karena itu mata pelajaran IPS dirancang untuk mengembangkan pengetahuan, pemahaman, dan kemampuan analisis terhadap kondisi sosial masyarakat dalam memasuki kehidupan bermasyarakat yang dinamis. Mata pelajaran IPS disusun secara sistematis, komprehensif, dan terpadu dalam proses pembelajaran menuju kedewasaan dan keberhasilan dalam kehidupan di masyarakat. Dengan pendekatan tersebut diharapkan peserta didik akan memperoleh pemahaman yang 
lebih luas dan mendalam pada bidang ilmu yang berkaitan. Mata pelajaran IPS bertujuan agar peserta didik memiliki kemampuan ,mengenal konsep-konsep yang berkaitan dengan kehidupan masyarakat dan lingkungannya, memiliki kemampuan dasar untuk berpikir logis dan kritis, rasa ingin tahu, inkuiri, memecahkan masalah, dan keterampilan dalam kehidupan sosial, memiliki komitmen dan kesadaran terhadap nilai-nilai sosial dan kemanusiaan, memiliki kemampuan berkomunikasi,bekerjasama dan berkompetisi dalam masyarakat yang majemuk, di tingkat lokal, nasional, dan global. Ruang lingkup mata pelajaran IPS meliputi aspek-aspek, manusia, tempat, dan lingkungan, waktu, keberlanjutan, dan perubahan, sistem sosial dan budaya, perilaku ekonomi dan kesejahteraan

Rendahnya aktivitas belajar IPS siswa kelas VIII.3 SMP Negeri 2 Banyuasin III Kabupaten Banyuasin berdasarkan data hasil observasi aktivitas belajar siswa ketika belajar dengan metode diskusi kelompok menggunakan Lembar Kerja Peserta Didik ( LKPD) rata-rata untuk mengikuti pembelajaran dengan penuh perhatian (50\%), mengajukan pertanyaan jika ada yang tidak dipahami (10\%), berperan aktif dalam kelompok (20\%), Menyerahkan tugas tepat waktu (20\%) sehingga perlu digunakan dan dicari alternatif lain dalam penggunaan metode dan media mengajar sehingga hasil belajar yang lebih baik dapat tercapai. Selain itu dalam proses pembelajaran masih sering ditemui adanya kecenderungan meminimalkan keterlibatan siswa. Dominasi guru dalam proses pembelajaran menyebabkan kecenderungan siswa lebih bersifat pasif sehingga mereka lebih banyak menunggu sajian guru dari pada mencari dan menemukan sendiri pengetahuan, ketrampilan atau sikap yang mereka butuhkan. Dalam pelaksanaannya pembelajaran IPS sangat menjemukan karena penyajiannya bersifat monoton dan ekspositoris sehingga siswa kurang antusias dan mengakibatkan pelajaran kurang menarik padahal guru IPS wajib berusaha secara optimum merebut minat siswa karena minat merupakan modal utama untuk keberhasilan pembelajaran IPS. Berdasarkan hasil observasi di SMP Negeri 2 Banyuasin III, pembelajaran IPS belum sesuai diharapkan. Hal ini disebabkan oleh: 
PENGGUNAAN HANDPHONE SEBAGAI MEDIA PEMBELAJARAN MELALUI

APLIKASI KINE MASTER UNTUK MENINGKATKAN MINAT BELAJAR IPS DI SMP

NEGERI 2 BANYUAS IN III

(Elli Iryani, S.Pd., M.Si.)

1. Kurangnya ketrampilan guru dalam memilih media yang tepat dalam pelaksanaan pembelajaran

2. Kurangnya ketrampilan guru untuk memanfaatkan media.

3. Minat belajar siswa kurang atau belum sesuai dengan apa yang diharapkan.

Semua itu menyebabkan pembelajaran tidak efektif dan pada akhirnya berdampak pada hasil belajar siswa yang rendah. Berdasarkan hasil analisis ulangan harian mata pelajaran IPS kelas VIII.3 SMP Negeri 2 Banyuasin III Kabupaten Banyuasin, nilai rata-rata hasil belajar siswa pada mata pelajaran IPS kelas VIII.3 masih rendah dengan nilai rata-rata $61,50 \%$ dan hasil belajar klasikal 50,50\% dengan kriteria ketuntasan minimal adalah $70 \%$.

Dalam pembelajaran IPS guru harus dapat menciptakan suasana belajar yang menyenangkan dan penuh antusias bagi siswa, kegiatan pembelajaran yang menyenangkan harus didukung oleh alat belajar yang menarik minat belajar sehingga siswa tidak merasa bosan selama mengikuti pembelajaran, sebagaimana dikemukakan oleh Samlawi Fakih (1992) bahwa mata pelajaran IPS adalah mata pelajaran yang membosankan, oleh karena itu diperlukan media yang dapat menarik minat siswa untuk belajar, dalam hal ini media yang tepat dapat merangsang siswa untuk lebih mengerti dan memahami materi yang diajarkan. Menurut Gagne (dalam Amidun Rasyad dan Darhim, 1996 - 1997:97) “media adalah jenis komponen dalam lingkungan siswa yang dapat merangsang untuk belajar". Belajar bukan saja melulu penerapan teori semata dan pembelajaran di ruang kelas, tetapi lebih dari itu belajar merupakan cara yang kompleks untuk meningkatkan kualitas sumber daya manusia sebuah bangsa. Oleh sebab itu, ketepatan memilih media pembelajaran merupakan faktor pendukung dalam sukses tidaknya guru mendidik murid menjadi generasi yang dapat diandalkan dan dibanggakan kelak. Oleh karena itu guru harus menggunakan media pembelajaran yang tidak saja membuat proses pembelajaran menjadi menarik, tetapi juga memberikan ruang bagi murid untuk berkreasi dan terlibat secara aktif sepanjang proses pembelajaran. Sehingga aspek kognitif, afektif dan psikomotorik murid pun dapat berkembang maksimal secara bersamaan tanpa mengalami pendistorsian salah satunya. Kenyataan apa yang menjadi harapan dan tujuan di atas belum sepenuhnya terpenuhi. Namun usaha ke arah itu senantiasa dilakukan 
oleh seluruh elemen pendidikan. Hal ini menunjukkan bahwa dengan penggunaan media yang tepat dalam pembelajaran akan menarik minat belajar siswa terutama pada mata pelajaran IPS.

Dengan media yang menarik materi pelajaran akan mudah diserap oleh siswa, karena dengan menggunakan media dapat mempermudah pemahaman belajar anak dalam pencapaian tujuan pengajaran. Materi tentang Munculnya Organisasi Pergerakan dan Tumbuhnya Semangat Kebangsaan adalah salah satu materi pada pelajaran IPS kelas VIII semester 2, tetapi ternyata guru dalam melaksanakan pembelajaran kebanyakan masih bersifat konvensional, artinya guru masih mendominasi jalannya pembelajaran dan belum memanfaatkan media pembelajaran secara maksimal sehingga pembelajaran yang dilakukan menjadi kurang menarik. Selain itu, guru belum sepenuhnya memanfaatkan alat peraga dalam pembelajaran Ilmu Pengetahuan Sosial . Untuk mengatasi hal tersebut perlu diadakan penggunaan media pembelajaran yang mudah didapat dan hampir semua peserta didik memilikinya yaitu melalui media handphone (HP).

Media pembelajaran yang dimaksud dalam penelitian ini adalah media yang digunakan untuk menunjang proses belajar mengajar khususnya pada mata pelajaran IPS terutama pada materi tentang Munculnya Organisasi Pergerakan dan Tumbuhnya Semangat Kebangsaan. Adapun media tersebut adalah handphone (HP). Harapan selanjutnya adalah ingin memperbaiki proses pembelajaran dengan memanfaatkan penggunaan alat peraga dan media teknologi komunikasi yang mudah didapat dan hampir semua peserta didik memilikinya. Diharapkan dengan menggunakan media HP lebih mewarnai proses pembelajaran agar pembelajaran lebih bermakna, materi mudah dipahami siswa, bergairah serta bernuansa PAIKEM (Aktif, Inovatif, Kreatif, Efektif dan Menyenangkan). Disisi lain siswa pun akhirnya akan lebih akrab dan lebih berminat belajar IPS serta prestasi belajar siswa meningkat.

Berdasarkan uraian di atas maka penulis melaksanakan penelitian tindakan kelas mengenai "Penggunaan Media Pembelajaran Dengan Aplikasi Kine Master Melalui Handphone Untuk Meningkatkan Minat Belajar Sis wa Kelas VIII. 3 Pada Mata Pelajaran IPS di SMP Negeri 2 Banyuasin III Kabupaten Banyuasin". 
PENGGUNAAN HANDPHONE SEBAGAI MEDIA PEMBELAJARAN MELALUI

APLIKASI KINE MASTER UNTUK MENINGKATKAN MINAT BELAJAR IPS DI SMP

NEGERI 2 BANYUAS IN III

(Elli Iryani, S.Pd., M.Si.)

\section{B. Masalah Penelitian}

\section{Identifikasi Masalah}

Berdasarkan uraian pada latar belakang maka permasalahan dapat diidentifikasi sebagai berikut :

a. Kurangnya ketrampilan guru dalam memilih media yang tepat dalam pembelajaran

b. Guru belum memanfaatkan ataupun menggunakan teknologi komunikasi handphone ( HP ) sebagai media pembelajaran

c. Minat belajar siswa kurang atau belum sesuai dengan apa yang diharapkan.

\section{Perumusan Masalah}

Rumusan masalah dalam penelitian ini adalah "Apakah penggunaan teknologi komunikasi handphone (HP) dapat meningkatkan minat belajar siswa kelas VIII.3 khususnya materi Munculnya Organisasi Pergerakan Semangat Kebangsaan pada mata pelajaran IPS di SMP Negeri 2 Banyuasin III Kabupaten Banyuasin ?".

\section{Pemecahan Masalah}

Dalam upaya memecahkan permasalahan tentang rendahnya minat belajar siswa dalam pembelajaran IPS, proses pembelajaran akan dilakukan dengan menggunakan media teknologi komunikasi handphone (HP)

\section{Tujuan Penelitian}

Tujuan yang hendak dicapai dalam penelitian ini adalah :

1. Untuk memperbaiki dan meningkatkan kemampuan guru (peneliti) melalui penggunaan media teknologi komunikasi handphone (HP) sehingga proses pembelajaran akan lebih baik.

2. Untuk meningkatkan minat belajar siswa dalam pembelajaran IPS dengan menggunakan media teknologi komunikasi handphone (HP).

\section{TINJAUAN PUSTAKA}

Teknologi berasal dari bahasa Yunani technologia, techne yang berarti keahlian dan logia/logos yang berarti pengetahuan. Dalam pengertian yang sempit teknologi mengacu pada objek benda yang dipergunakan untuk kemudahan aktivitas manusia seperti mesin, perkakas atau perangkat keras. Pengertian 
teknologi menurut Read Bain (1937) "teknologi pada dasarnya meliputi semua alat, mesin, perkakas, aparat, senjata, perumahan, pakaian, peranti pengangkut, komunikasi dan juga ketrampilan dimana hal ini memungkinkan kita sebagai manusia dapat menghasilkan semua itu". Awalnya teknologi hanya untuk membantu manusia dalam memenuhi kebutuhannya, tetapi seiring perkembangan zaman terjadilah pengalihan fungsi teknologi. Seperti handphone, dulu handphone hanya digunakan untuk sarana berkomunikasi dan hanya digunakan oleh kalangan-kalangan tertentu saja, namun seiring perkembangan zaman handphone kini semakin lengkap dengan adanya fitur-fitur menarik seperti internet, games, music, video, kamera dll yang digunakan oleh semua kalangan mulai dari orangtua,dewasa, remaja bahkan anak-anak, handphone kini bukan sekedar alat komunikasi melainkan sudah menjadi gaya hidup sebagian besar masyarakat.

Seiring dengan konsep pembelajaran yang memanfaatkan perangkat elektronik atau e-learnig yaitu untuk mengatasi batas ruang dan waktu sehingga proses belajar mengajar dapat dilakukan kapan dan dimana saja, dalam hal ini handphone berperan sebagai media pembelajaran dimana handphone merupakan salah satu perangkat teknologi yang paling praktis dan bisa digunakan untuk membantu proses belajar mengajar.

Aplikasi Kine Master merupakan salah satu aplikasi pembuat video yang bisa di download pada play store yang bisa dijadikan sebagai media pembelajaran untuk mewujudkan pembelajaran IPS yang aktif, kreatif, dan menyenangkan bagi peserta didik. Pemanfaatan media handphone dengan menggunakan aplikasi kine master diperlukan strategi yang tepat, hal ini dimaksudkan agar pelajaran tidak terjebak pada sifat monoton dan siswa tidak hanya menonton guru menjelaskan materi pembelajaraan tetapi diajak untuk ikut berpartisipsi aktif dalam proses pembelajaran yang mengacu kepada ketrampilan abad 21 yaitu 4C (communication, collaborative, critical thinking and creativity). Pembelajaran IPS dengan materi Munculnya Organisasi Pergerakan dan Tumbuhnya Semangat Kebangsaan dapat diawali dengan penjelasan singkat dari guru tentang cara pembuatan video pembelajaran dengaan menggunakan aplikasi kine master, guru memberikan dan mengajarkan secara singkat bagaimana proses untuk pembuatan video pembelajaran tersebut, sehingga dapat membawa suasana belajar sesuai 
PENGGUNAAN HANDPHONE SEBAGAI MEDIA PEMBELAJARAN MELALUI

APLIKASI KINE MASTER UNTUK MENINGKATKAN MINAT BELAJAR IPS DI SMP

NEGERI 2 BANYUAS IN III

(Elli Iryani, S.Pd., M.Si.)

dengan tujuan yang diharapkan, kemudian dilanjutkan meminta siswa untuk mendownload aplikasi kine master tersebut pada handphone siswa masing-masing dan membagi materi pembelajaran yang akan dibuat videonya.

Minat belajar siswa adalah modal bagi siswa untuk melakukan aktivitas belajar dalam usaha mencapai perubahan perilaku. Perubahan perilaku yang dimaksudkan adalah dari perilaku tidak tahu menjadi tahu dan dari perilaku tidak mengetahui menjadi perilaku mengetahui. Minat pada umumnya sudah terdapat dalam diri seseorang. Akan tetapi biasanya minat juga dapat dipengaruhi oleh sesuatu yang berasal dari luar atau yang sering disebut motivasi atau dorongan. Jika minat yang terdapat dalam diri seseorang sudah cukup kuat, maka dorongan yang berasal dari luar relatif kurang diperlukan. Tetapi sebaliknya, jika seseorang kurang memiliki minat, maka diperlukan dorongan dari luar atau motivasi ekstrinsik yang relatif kuat.

\section{METODE PENELITIAN}

\section{A. Tempat dan Subyek Penelitian}

Penelitian tindakan kelas ini dilaksanakan di SMP Negeri 2 Banyuasin III Kabupaten Banyuasin kelas VIII.3 semester genap tahun pelajaran 2019/2020 dengan jumlah siswa 30 orang terdiri 10 siswa laki-laki dan 20 siswa perempuan. Siswa kelas VIII.3 sebagai subyek penelitian ini memiliki karakteristik yang heterogen. Heterogen baik dalam segi kemampuan intelegensi, motivasi belajar, latar belakang keluarga, maupun sifat dan wataknya. Dari segi watak ada beberapa siswa yang memiliki watak sulit diatur, sehingga kadang-kadang menyulitkan guru pada saat pembelajaran berlangsung. Namun secara umum memiliki kepribadian yang cukup baik. Permasalahan tersebut mungkin dikarenakan semangat belajar yang kurang. Keadaan tersebut dapat dilihat keadaan sehari-hari, di mana siswa sering mengeluh merasa kesulitan untuk menerima materi sejarah yang telah lampau karena kebanyakan penyajian dari guru yang hanya berupa ceramah tentang kejadian masa lampau. Permasalahan inilah yang mendorong peneliti mengangkat mata pelajaran IPS dengan materi munculnya organisasi pergerakan dan tumbuhnya semangat kebangsaan untuk 
meningkatkan optimisme generasi muda seperti para pejuang yang telah rela berkorban untuk kemerdekaan dan kemajuan bagi bangsa dan negaranya.

\section{B. Waktu Penelitian}

Penelitian ini dilaksanakan selama kurang lebih 2 bulan yaitu dari awal bulan Maret 2020 sampai dengan bulan April 2020. waktu ini meliputi kegiatan persiapan sampai penyusunan laporan penelitian dengan jadwal sebagai berikut

Tabel 1

Jadwal Penelitian Tindakan Kelas Periode Awal Maret - April 2020

\begin{tabular}{|c|l|l|l|}
\hline N. & \multicolumn{1}{|c|}{ Bulan } & \multicolumn{1}{|c|}{ Kegiatan } & \multicolumn{1}{c|}{ Keterangan } \\
\hline 1. & Awal Maret & Pra Siklus & Proses Pembelajaran \\
\hline 2. & $\begin{array}{l}\text { Pertengahan } \\
\text { Maret }\end{array}$ & Siklus I & $\begin{array}{l}\text { PTK mengguna } \\
\text { kan media belajar }\end{array}$ \\
\hline 3. & Akhir Maret & Siklus II & $\begin{array}{l}\text { Pelaksanaan refleksi dari tindakan } \\
\text { siklus II }\end{array}$ \\
\hline 3. & April & $\begin{array}{l}\text { Laporan } \\
\text { Penelitian }\end{array}$ & $\begin{array}{l}\text { Penyusunan PTK (Penelitian Tindakan } \\
\text { Kelas) }\end{array}$ \\
\hline
\end{tabular}

\section{Jenis Data dan Teknik Pengumpulan Data}

1. Jenis Data

Jenis data yang didapat adalah data kuantitatif dan kualitatif, yaitu sebagai berikut:

a. Data minat siswa diambil dengan cara pemberian angket kepada siswa setelah selesai setiap siklus.

b. Data aktivitas belajar siswa dan pelaksanaan pembelajaran diperoleh dari hasil pengamatan kolaborator selama pelaksanaan tindakan tiap siklus dengan menggunakan instrument observasi kegiatan guru dan siswa pada saat KBM.

c. Data hasil belajar diambil dengan cara memberikan tes kepada siswa setelah selesai tindakan.

2. Teknik Pengumpulan Data

Teknik pengumpulan data pada penelitian ini dilakukan dengan empat cara, yaitu :

a. Observasi 
PENGGUNAAN HANDPHONE SEBAGAI MEDIA PEMBELAJARAN MELALUI

APLIKASI KINE MASTER UNTUK MENINGKATKAN MINAT BELAJAR IPS DI SMP

NEGERI 2 BANYUAS IN III

(Elli Iryani, S.Pd., M.Si.)

Observasi dilakukan oleh peneliti dan pengamat (teman sejawat). yaitu Rolinah, S.Pd, dan Kamil Ihsan, S.Pd. Observasi dalam penelitian ini adalah observasi langsung yaitu peneliti dan pengamat melihat dan mengamati secara langsung kemudian mencatat perilaku dan kejadian yang terjadi pada keadaan yang sebenarnya. Observasi dilakukan selama proses pembelajaran dari kegiatan awal sampai kegiatan akhir. Dalam observasi ini peneliti lebih banyak menggunakan salah satu dari panca indera yaitu indra penglihatan. Instrumen observasi akan lebih efektif jika informasi yang hendak diambil berupa kondisi atau fakta alami, tingkah laku dan hasil kerja responden dalam situasi alami. Sebaliknya, instrumen observasi mempunyai keterbatasan dalam menggali informasi yang berupa pendapat atau persepsi dari subyek yang diteliti (Soekowati, 2006:64).

2. Tes

Tes dilakukan untuk mengetahui kemampuan awal siswa sehingga peneliti dapat merencanakan tindakan yang akan diambil dalam memperbaiki proses pembelajaran. Pemberian tindakan dilakukan melalui tiga siklus dan evaluasi dilakukan diakhir siklus untuk mengetahui prestasi belajar siswa pada setiap siklus. Tes adalah suatu alat pengumpul informasi, bersifat lebih resmi karena penuh dengan batasan-batasan (Arikunto, 2005:33).

3. Wawancara

Wawancara pada penelitian ini menggunakan wawancara tidak berstruktur karena peneliti memandang model ini adalah yang paling luwes, di mana subyek diberi kebebasan untuk menguraikan jawabannya dan ungkapan-ungkapan pandangannya secara bebas dan sesuai hatinya. Wawancara ini digunakan untuk mendapatkan data tentang pendapat siswa mengenai pengetahuannya tentang organisasi pergerakan dan tumbuhnya semangat kebangsaan.

4. Kuisioner

Pemberian kuisioner/angket untuk setiap siklus untuk mengetahui umpan balik terhadap pemberian materi organisasi pergerakan dan tumbuhnya semangat kebangsaan yang telah diberikan kepada siswa. 


\section{Teknik Analisis Data}

Data yang terkumpul dianalisis secara deskriptif kualitatif, yaitu membandingkan minat belajar sebelum tindakan dengan sesudah tindakan. 1. Data tentang minat belajar siswa

Data tentang minat belajar siswa dalam pembelajaran dengan menggunakan media visual dianalisis dengan menggunakan persamaan:

$\%$ aspek minat belajar siswa $=$

Jumlah siswa yang minat $X 100 \%$

Jumlah siswa keseluruhan

2. Data tentang aktivitas belajar siswa

Data tentang aktivitas belajar siswa dengan menggunakan media HP dapat dianalisis dengan menggunakan persamaan:

$\%$ aktivitas belajar siswa $=$

Jumlah siswa beraktivitas $X 100 \%$

Jumlah siswa keseluruhan

3. Data tentang hasil belajar siswa

Data tentang hasil belajar siswa dengan menggunakan media visual dianalisis dengan menggunakan persamaan:

$\%$ indikator belajar siswa $=$

Jumlah skor yg diperoleh X 100\%

Jumlah siswa keseluruhan

Data tentang hasil belajar dikatakan tuntas bila sesuai KKM yaitu 70,00

4. Data aktivitas siswa dan minat belajar tercapai apabila secara klasikal $70 \%$ siswa telah melaksanakan evaluasi hasil belajar dari materi organisasi pergerakan dan tumbuhnya semangat kebangsaan

Setelah data dianalisis, maka langkah selanjutnya dilakukan teknik analisis data yang berfungsi untuk pengujian data yang telah dianalisis dengan menggunakan reduksi data, penyajian data, penarikan simpulan, serta verifikasi refleksi.

1. Reduksi Data

Dalam reduksi data yang diperoleh dari hasil observasi dan wawancara ditulis dalam bentuk rekaman data, dikumpulkan, dirangkum, dan dipilih hal-hal yang pokok, kemudian dicari polanya. Jadi, rekaman data sebagai bahan data 
PENGGUNAAN HANDPHONE SEBAGAI MEDIA PEMBELAJARAN MELALUI

APLIKASI KINE MASTER UNTUK MENINGKATKAN MINAT BELAJAR IPS DI SMP

NEGERI 2 BANYUAS IN III

(Elli Iryani, S.Pd., M.Si.)

mentah singkat disusun lebih sistematis, ditonjolkan pokok-pokok yang penting sehingga lebih tajam hasil pengamatan dalan penelitian ini, juga mempermudah peneliti untuk mencatat kembali data yang diperoleh bila diperlukan.

2. Penyajian Data

Data yang telah direduksi dan dikelompokkan dalam berbagai pola dideskripsikan dalam bentuk kata-kata yang berguna untuk melihat gambaran keseluruhan/bagian tertentu. Penyajian data ini ditulis dalam paparan data.

3. Penarikan Simpulan, Verifikasi, dan Refleksi

Data yang diperoleh dicari pola, hubungan, atau hal-hal yang sering timbul dari data tersebut kemudian dihasilkan simpulan sementara yang disebut dengan temuan peneliti. Penarikan simpulan dilakukan terhadap temuan peneliti berupa indikator-indikator yang selanjutnya dilakukan pemaknaan atau refleksi sehingga memperoleh simpulan akhir. Hasil simpulan akhir dilakukan refleksi untuk menentukan atau menyusun rencana tindakan berikutnya.

\section{E. Pelaksanaan Penelitian}

Dalam pelaksanaannya penelitian ini dilakukan secara kolaboratif dengan guru mata pelajaran IPS. Penelitian tindakan kelas dilaksanakan dalam dua siklus. Setiap siklus terdiri dari empat langkah yaitu perencanaan (Planning), pelaksanaan (actuating), observasi (observing), dan refleksi (reflecting). Prosedur penelitian tindakan kelas dilakukan secara bertahap mulai dari kegiatan awal (pra siklus), pelaksanaan tindakan siklus pertama dan siklus ke dua.

\section{HASIL DAN PEMBAHASAN}

Penelitian ini dilaksanakan di kelas VIII.3 SMP Negeri 2 Banyuasin III Kabupaten Banyuasin dengan jumlah siswa 30 orang, yang terdiri dari 10 orang siswa laki- laki dan 22 orang siswa perempuan. Menurut pengamatan peneliti secara fisik dan intelegensi bahwa siswa kelas VIII.3 memiliki kecakapan yang hampir sama atau rata- rata. Hal ini dapat dilihat pada aktivitas dan minat belajar siswa kelas VIII.3 mengenai materi organisasi pergerakan dan tumbuhnya semangat kebaangsaan di saat melaksanakan observasi awal yang menjadi landasan peneliti dalam melakukan tindakan. 


\section{a. Observasi Awal}

Dari observasi awal yang peneliti lakukan ternyata banyak didapati masalah-masalah serta kelemahan- kelemahan siswa, sehingga siswa tidak tertarik dengan mata pelajaran IPS khususnya tentang sejarah (Organisasi pergerakan dan tumbuhnya semangat kebangsaan). Hal ini disebabkan oleh:

1. Kurangnya keterampilan guru dalam memilih media yang tepat dalam pembelajaran

2. Guru belum memanfaatkan/ menggunakan media yang disukai oleh siswa

3. Minat belajar siswa kurang atau belum sesuai dengan apa yang diharapkan.

Masalah yang paling menonjol yaitu dalam melaksanakan pembelajaran kebanyakan masih bersifat konvensional, artinya guru masih mendominasi jalannya pembelajaran dan belum memanfaatkan media pembelajaran secara maksimal sehingga pembelajaran yang dilakukan cenderung kurang menarik bagi siswa. Selain itu guru belum sepenuhnya memanfaatkan alat peraga dalam pembelajaran Ilmu Pengetahuan Sosial. Kebanyakan masih menggunakan lembar kerja yang dibeli. Untuk mengatasi hal itu perlu diadakan uji coba menggunakan media pembelajaran yaitu melalui media Handphone (HP) yang saat ini sudah menjadi bagian yang tak terpisahkan dari kehidupan manusia. Melihat kondisi tersebut peneliti berkolaborasi dengan guru mata pelajaran IPS hendak memperbaiki minat belajar siswa ini dengan memperhatikan hal-hal yang harus dibenahi seperti alat atau media yang dapat menarik minat siswa dengan memanfaatkan media HP dalam proses pembelajaran.

\section{b. Tindakan Siklus I}

Setelah dilakukan observasi awal dan diketahui minat belajar siswa, maka langkah yang selanjutnya adalah dilakukannya tindakan siklus I yang terdiri dari empat tahap. Tahapan- tahapan tersebut adalah sebagai berikut:

\section{Tahap Perencanaan}

Pada tahap perencanaan ini peneliti terlebih dahulu mendiskusikan dengan guru mata pelajaran IPS tentang permasalahan pembelajaran dan tindakan yang direncanakan, menyusun perangkat pembelajaran berupa rencana pembelajaran yang disetting sebagai PTK, bahan pengajaran yang akan diberikan, menyiapkan media pembelajaran pendukung, bahan tugas untuk siswa, kisi- kisi 
PENGGUNAAN HANDPHONE SEBAGAI MEDIA PEMBELAJARAN MELALUI

APLIKASI KINE MASTER UNTUK MENINGKATKAN MINAT BELAJAR IPS DI SMP

NEGERI 2 BANYUAS IN III

(Elli Iryani, S.Pd., M.Si.)

soal, alat evaluasi serta menyusun alat evaluasi bersama guru mitra, menyusun lembar kerja siswa bersama guru, menyusun lembar observasi aktivitas siswa dan guru bersama guru mitra.

Dari hasil kesepakatan peneliti bersama kolaborator untuk memanfaatkan media handphone (HP) sebagai media yang akan digunakan, pelaksanaan siklus I ini diadakan dua kali pertemuan. Hal ini bertujuan untuk melihat aktivitas siswa dalam meningkatkan minat belajar IPS terutama dalam materi organisasi pergerakan dan tumbuhnya semangat kebangsaan.

2. Tahap Tindakan

Penelitian ini dilaksanakan secara kolaboratif dengan guru mata pelajaran IPS. Adapun kegiatannya sebagai berikut:

\section{Pertemuan Pertama}

Dalam pertemuan ini membahas materi tentang latar belakang munculnya organisasi pergerakan dan tumbuhnya semagat kebangsaan dengan urutan kegiatan yang dilakukan adalah sebagai berikut:

a. Guru memberikan pertanyaan kepada siswa "Apakah kalian mengetahui negara-negara mana saja yang pernah menjajah Indonesia?" sebagai prasayarat untuk dapat mengikuti pembahasan mengenai penggunaan teknologi komunikasi handphone (HP) khususnya materi munculnya organisasi pergerakan dan tumbuhnya semangat kebangsaan.

b. Guru memberikan motivasi kepada siswa dengan menayangkan contoh bentuk video pembelajaran dengan menggunakan aplikasi kine master lewat OHP mengenai materi munculnya organisasi pergerakan dan tumbuhnya semangat kebangsaan.

c. Guru menjelaskan rencana kegiatan dan tujuan pembelajaran.

d. Guru memberikan penjelasan mengenai cara penggunaan teknologi komunikasi handphone (HP) untuk membuat video pembelajaran.

e. Guru memberikan pembagian tugas membuat video pembelajaran sesuai materi yang telah dibagi yang dikerjakan secara individual.

f. Guru berkeliling mengawasi dan memberibimbingan kepada siswa yang kurang mengerti. 
g. Setelah cukup diberi waktu 30 menit guru bersama siswa membahas pembuatan video pembelajaran dan menunjuk salah satu siswa untuk menampilkannya di depan kelas dengan menggunakan OHP.

h. Selesai melihat hasil video yang dibuat siswa, guru menanyakan pada siswa bagian mana yang belum dikuasai dan dipahami siswa untuk membuat videonya menjadi menarik.

i. Guru membimbing siswa memperbaiki videonya agar lebih menarik.

j. Guru memberikan tugas/PR kepada siswa untuk mengedit videonya agar menjadi menarik untuk dibahas pada pertemuan berikutnya.

Pertemuan Kedua

Kegiatan yang dilakukan dalam pertemuan ini adalah sebagai berikut:

a. Guru membahas PR dan menerangkan bagian-bagian yang belum dikuasai siswa untuk membuat video.

b. Guru memberikan soal test sesuai materi video yang di buat oleh masingmasing siswa pada siklus I dengan waktu 40 menit.

c. Guru mengoreksi hasil kerja siswa dan mempersentasikan hasil tes siklus I

3. Tahap Pengamatan (observasi)

Mengingat dalam penelitian ini dilaksanakan secara kolaboratif dengan guru, maka pada tahap pengamatan (observasi) aktivitas belajar siswa selama kegiatan pembelajaran berlangsung dipantau oleh peneliti dan dibantu oleh salah seorang pengamat dengan menggunakan pedoman lembar observasi aktivitas siswa. Aktivitas siswa dalam pembelajaran IPS mengenai organisasi pergerakan dan tumbuhnya semangat kebangsaan dengan menggunakan media handphone pada siklus I masih kurang, hal ini terlihat dalam beberapa aspek penilaian aktivitas belajar siswa dapat dilihat dalam tabel berikut ini: 
PENGGUNAAN HANDPHONE SEBAGAI MEDIA PEMBELAJARAN MELALUI

APLIKASI KINE MASTER UNTUK MENINGKATKAN MINAT BELAJAR IPS DI SMP

NEGERI 2 BANYUAS IN III

(Elli Iryani, S.Pd., M.Si.)

Tabel 2

Siklus 1 : Rekapitulasi Aktivitas Belajar Siswa

\begin{tabular}{|c|l|c|c|}
\hline No & \multicolumn{1}{|c|}{ Aspek } & $\begin{array}{c}\text { Jumlah Persentase } \\
(\%)\end{array}$ & Keterangan \\
\hline 1 & Bertanya & $18,56 \%$ & Belum Tuntas \\
\hline 2 & Antusias & $23,72 \%$ & Tuntas \\
\hline 3 & Mencari materi video & $20,63 \%$ & Belum Tuntas \\
\hline 4 & $\begin{array}{l}\text { Bersedia membantu } \\
\text { teman }\end{array}$ & $26,81 \%$ & Tuntas \\
\hline
\end{tabular}

Berdasarkan tabel di atas aktivitas siswa dalam aspek bertanya dan mencari sumber belajar perlu ditingkatkan. Sedangkan aspek bekerjasama melampui target yang ditentukan, yaitu 26,81\%. Sedangkan hasil angket siswa setelah kegiatan belajar mengajar minat siswa dalam belajar IPS dengan menggunakan media handphone dapat dilihat dalam rekapitulasi tabel berikut ini

Tabel 3

Siklus I : Rekapitulasi Minat Belajar Siswa

\begin{tabular}{|c|l|c|c|}
\hline No & \multicolumn{1}{|c|}{ Aspek } & $\begin{array}{c}\text { Jumlah } \\
\text { Persentase (\%) }\end{array}$ & Ket \\
\hline 1 & $\begin{array}{l}\text { Tidak Pernah Meninggalkan } \\
\text { Pelajaran }\end{array}$ & $20,52 \%$ & Tuntas \\
\hline 2 & Mengerjakan Tugas Dengan Baik & $20,49 \%$ & Tuntas \\
\hline 3 & Fokus/Konsentrasi & $18,36 \%$ & Tuntas \\
\hline 4 & $\begin{array}{l}\text { Maksimal Dalam Mengerjakan } \\
\text { Tugas Mata Pelajaran IPS }\end{array}$ & $19,43 \%$ & Tuntas \\
\hline 5 & Tepat Waktu Mengumpulkan Tugas & $21,20 \%$ & Tuntas \\
\hline
\end{tabular}

Berdasarkan nilai hasil belajar siswa didapat dengan rata-rata 73.50, yang berarti telah memenuhi standar KKM yang ditentukan dalam mata pelajaran IPS yaitu 70.00 . 


\section{Tahap Refleksi}

Setelah dilakukannya pelaksanaan maka diadakan refleksi. Kegiatan ini berguna untuk mengetahui ada tidaknya peningkatan aktivitas belajar dan minat belajar siswa sebelum dan sesudah tindakan yang nantinya digunakan sebagai bahan pertimbangan pelaksanaan siklus berikutnya. Berdasarkan hasil refleksi dalam kegiatan pembelajaran secara keseluruhan guru dalam melaksanakan proses pembelajaran berjalan sesuai dengan RPP, tetapi ada yang perlu diperhatikan oleh guru yaitu hendaknya guru memberikan bimbingan lebih intens lagi berkeliling pada setiap siswa agar pembelajaran efektif selain ada yang ditayangkan dalam LCD. Peneliti menyimpulkan bahwa tindakan yang dilakukan ini belum mencapai indikator kinerja yang sesuai dengan harapan khususnya pada aspek konsentrasi dalam belajar IPS dan maksimal dalam mengerjakan tugas mata pelajaran IPS sehingga dilanjutkan ke siklus berikutnya.

\section{a. Tindakan Siklus II}

\section{Tahap Perencanaan}

Berdasarkan hasil refleksi pada siklus I baik yang berkaitan dengan siswa, guru ataupun perangkat, maka diadakan perencanaan ulang meliputi:

a. Pendekatan, strategi, metode dan media pembelajaran

b. Menciptakan suasana belajar yang lebih melibatkan keaktifan siswa

c. Menyusun struktur pembelajaran yang lebih efektif dan efisien

d. Pengelolaan kelas

Perencanaan yang lainnya sama sebagaimana pada perencanaan siklus pertama.

2. Tahap Tindakan

Kegiatan yang dilakukan dalam pertemuan ini adalah sebagai berikut:

\section{Pertemuan Ketiga}

Dalam pertemuan ini melakukan kegiatan pertukaran video pembelajaran yang telah dibuat oleh masing-masing siswa sebagai berikut :

a. Guru memberikan perintah kepada siswa untuk saling bertukar video pembelajaran yang telah mereka buat.

b. Guru mengatur mekanisme pertukaran video di antara siswa. 
PENGGUNAAN HANDPHONE SEBAGAI MEDIA PEMBELAJARAN MELALUI

APLIKASI KINE MASTER UNTUK MENINGKATKAN MINAT BELAJAR IPS DI SMP

NEGERI 2 BANYUAS IN III

(Elli Iryani, S.Pd., M.Si.)

c. Guru memberikan soal latihan berupa lembar kerja siswa yang dapat dikerjakan secara individu dengan materi pertukaran video yang telah dilakukan oleh siswa sebelumnya.

d. Guru berkeliling mengawasi dan memberi bimbingan kepada siswa yang kurang mengerti.

e. Setelah cukup diberi waktu 30 menit guru bersama siswa membahas soal latihan dengan cara menunjuk siswa untuk memaparkan di depan kelas, dengan bimbingan guru siswa lain mencocokkan hasil kerjanya.

f. Selesai membahas latihan-latihan soal, guru menanyakan pada siswa soalsoal manakah yang belum dikuasai ataupun yang sudah dikuasai oleh siswa.

g. Guru membimbing siswa untuk membuat rangkuman.

h. Guru memberikan motivasi kepada siswa untuk mengulangi penjelasan mengenai materi organisasi pergerakan dan tumbuhnya semangat kebangsaan

3. Tahap Pengamatan (Observasi)

Observasi dilakukan sebagaimana pada siklus I, yaitu pada tahap pengamatan (observasi), aktivitas siswa selama proses pembelajaran dipantau langsung oleh peneliti dan dibantu oleh salah seorang pengamat dengan menggunakan pedoman lembar observasi aktivitas siswa. Aktivitas siswa dalam pembelajaran IPS mengenai materi organisasi pergerakan dan tumbuhnya semangat kebangsaan dengan menggunakan media handphone pada siklus II sudah baik, hal ini terlihat dalam beberapa aspek penilaian aktivitas belajar siswa.

Tabel 4

Siklus II : Rekapitulasi Aktivitas Belajar Siswa

\begin{tabular}{|c|l|c|c|}
\hline No & \multicolumn{1}{|c|}{ Aspek } & $\begin{array}{c}\text { Jumlah Persentase } \\
(\boldsymbol{\%})\end{array}$ & Keterangan \\
\hline 1 & Bertanya & $20,60 \%$ & Tuntas \\
\hline 2 & Antusias & $26,75 \%$ & Tuntas \\
\hline 3 & Mencari materi video & $21,85 \%$ & Tuntas \\
\hline 4 & Bersedia membantu teman & $30,80 \%$ & Tuntas \\
\hline
\end{tabular}


Berdasarkan tabel di atas aktivitas siswa dalam aspek bertanya dan mencari sumber belajar perlu ditingkatkan. Sedangkan aspek bekerjasama melampui target yang ditentukan yaitu 30,80\%. Sedangkan hasil angket siswa setelah kegiatan belajar mengajar minat siswa dalam belajar IPS dengan menggunakan media handphone (HP) dapat dilihat dalam rekapitulasi tabel berikut ini:

Tabel 5

Siklus II : Rekapitulasi Minat Belajar Siswa

\begin{tabular}{|c|l|c|c|}
\hline No & \multicolumn{1}{|c|}{ Aspek } & Jumlah Persentase (\%) & Keterangan \\
\hline 1 & $\begin{array}{l}\text { Tidak Pernah Meninggalkan } \\
\text { Pelajaran }\end{array}$ & $23,88 \%$ & Tuntas \\
\hline 2 & $\begin{array}{l}\text { Mengerjakan Tugas Dengan } \\
\text { Baik }\end{array}$ & $22,84 \%$ & Tuntas \\
\hline 3 & Fokus/Konsentrasi & $20,75 \%$ & Tuntas \\
\hline 4 & $\begin{array}{l}\text { Maksimal Dalam } \\
\text { Mengerjakan Tugas Mata } \\
\text { Pelajaran IPS }\end{array}$ & $21,81 \%$ & Tuntas \\
\hline 5 & $\begin{array}{l}\text { Tepat Waktu Mengumpulkan } \\
\text { Tugas }\end{array}$ & $25,94 \%$ & Tuntas \\
\hline
\end{tabular}

Berdasarkan nilai hasil belajar siswa didapat dengan rata-rata 82,50 yang berarti telah memenuhi standar KKM yang ditentukan dalam mata pelajaran IPS yaitu 70.00 .

\section{A. Pembahasan}

Dari hasil refleksi dan deskripsi data yang telah diuraikan tersebut bahwa ternyata dari segi hasil aktivitas belajar, minat belajar dan segi indikator belajar siswa yang diadakan oleh peneliti pada pra siklus dan siklus I belum mencapai hasil yang optimal. Hal ini ditunjukkan dengan masih kurangnya minat siswa dalam menggunakan media handphone (HP) terutama pada pembelajaran IPS mengenai materi organisasi pergerakan dan tumbuhnya semangat kebangsaan. Peneliti menyimpulkan bahwa tindakan yang dilakukan ini belum mencapai indikator kinerja yang sesuai dengan harapan dan akan dilanjutkan ke siklus berikutnya. 
PENGGUNAAN HANDPHONE SEBAGAI MEDIA PEMBELAJARAN MELALUI

APLIKASI KINE MASTER UNTUK MENINGKATKAN MINAT BELAJAR IPS DI SMP

NEGERI 2 BANYUAS IN III

(Elli Iryani, S.Pd., M.Si.)

Dari hasil refleksi dan deskripsi data yang telah diuraikan tersebut bahwa dari segi hasil aktivitas belajar, minat belajar dan segi indikator belajar siswa yang diadakan oleh peneliti sudah mencapai hasil yang optimal. Hal ini ditunjukkan dengan nampaknya minat belajar siswa dalam menggunakan media handphone terutama pada pembelajaran IPS mengenai materi organisasi pergerakan dan tumbuhnya semangat kebangsaan. Melihat minat belajar siswa kelas VIII.3 SMPN 2 Banyuasin III Kabupaten Banyuasin yang dicapai dari siklus I dan siklus II berarti semakin memperjelas adanya manfaat dari penggunaan media handphone dalam pembelajaran IPS terutama adanya peningkatan, hal dapat dilihat dari tabel berikut ini:

Tabel 6

Rekapitulasi Aktivitas Belajar Siswa

\begin{tabular}{|c|l|c|c|c|}
\hline No & \multicolumn{1}{|c|}{ Aspek } & Siklus I (\%) & Siklus II (\%) & $\begin{array}{c}\text { Peningkatan } \\
(\%)\end{array}$ \\
\hline 1 & Bertanya & $18,56 \%$ & $20,60 \%$ & $2,04 \%$ \\
\hline 2 & Antusias & $23,72 \%$ & $26,75 \%$ & $3,03 \%$ \\
\hline 3 & Mencari materi video & $20,63 \%$ & $21,85 \%$ & $1,22 \%$ \\
\hline 4 & $\begin{array}{l}\text { Bersedia membantu } \\
\text { teman }\end{array}$ & $26,81 \%$ & $30,80 \%$ & $3,99 \%$ \\
\hline
\end{tabular}

Sedangkan peningkatan minat belajar IPS dengan menggunakan media handphone (HP) dapat dilihat dalam tabel berikut:

Tabel 7

Rekapitulasi Minat Belajar Siswa

\begin{tabular}{|c|l|c|c|c|}
\hline No & \multicolumn{1}{|c|}{ Aspek } & $\begin{array}{c}\text { Siklus I } \\
(\boldsymbol{\%})\end{array}$ & $\begin{array}{c}\text { Siklus II } \\
(\boldsymbol{\%})\end{array}$ & $\begin{array}{c}\text { Peningkatan } \\
(\boldsymbol{\%})\end{array}$ \\
\hline 1 & $\begin{array}{l}\text { Tidak Pernah Meninggalkan } \\
\text { Pelajaran }\end{array}$ & $20,52 \%$ & $23,88 \%$ & $3,36 \%$ \\
\hline 2 & $\begin{array}{l}\text { Mengerjakan Tugas Dengan } \\
\text { Baik }\end{array}$ & $20,94 \%$ & $22,84 \%$ & $1,9 \%$ \\
\hline
\end{tabular}




\begin{tabular}{|c|l|c|c|c|}
\hline 3 & $\begin{array}{l}\text { Fokus/Konsentrasi Dalam } \\
\text { Belajar IPS }\end{array}$ & $18,36 \%$ & $20,75 \%$ & $2,39 \%$ \\
\hline 4 & $\begin{array}{l}\text { Maksimal Dalam } \\
\text { Mengerjakan Tugas Mata } \\
\text { Pelajaran IPS }\end{array}$ & $19,43 \%$ & $21,81 \%$ & $2,38 \%$ \\
\hline 5 & $\begin{array}{l}\text { Tepat Waktu } \\
\text { Mengumpulkan Tugas }\end{array}$ & $21,20 \%$ & $25,94 \%$ & $4,74 \%$ \\
\hline
\end{tabular}

Berdasarkan deskripsi yang dijelaskan pada pembahasan tersebut, maka jelaslah bahwa media handphone (HP) telah berhasil meningkatkan aktivitas belajar siswa sesuai dengan indikator yang diharapkan dan mengalami peningkatan sebesar $10,28 \%$, sedangkan minat belajar siswa untuk mengikuti proses pembelajaran IPS dengan materi organisasi pergerakan dan tumbuhnya semangat kebangsaan juga mengalami peningkatan, yaitu $14,77 \%$. Daya serap yang diperoleh selama proses pembelajaran dapat dilihat terjadinya peningkatan hasil belajar, seperti terlihat pada tabel berikut ini :

Tabel 8

Hasil Belajar Setelah Menggunakan Media Belajar

\begin{tabular}{|c|c|c|c|}
\hline No & $\begin{array}{c}\text { Rerata Nilai UH } \\
\text { Siklus I }\end{array}$ & $\begin{array}{c}\text { Rerata Nilai UH } \\
\text { Siklus II }\end{array}$ & Peningkatan \\
\hline 1 & 73,50 & 82,50 & 0,9 \\
\hline
\end{tabular}

Dengan demikian, maka hipotesis tindakan yang berbunyi "Jika Dalam Pembelajaran IPS Khususnya Materi Organisasi Pergerakan dan Tumbuhnya semangat Kebangsaan Diajarkan Dengan Menggunakan Media Handphone, Maka Minat Belajar Siswa Kelas VIII.3 SMP Negeri 2 Banyuasin III Kabupaten Banyuasin Akan Meningkat dan Dapat Diterima".

\section{SIMPULAN DAN SARAN}

\section{A. Kesimpulan}

Dengan pelaksanaanpembelajaran IPS pada materi organisasi pergerakan dan tumbuhnya semangat kebangsaan dengan menggunakan media handphone (HP) yang dilaksanakan pada penelitian siklus I dan siklus II, maka dapat ditarik 
PENGGUNAAN HANDPHONE SEBAGAI MEDIA PEMBELAJARAN MELALUI

APLIKASI KINE MASTER UNTUK MENINGKATKAN MINAT BELAJAR IPS DI SMP

NEGERI 2 BANYUAS IN III

(Elli Iryani, S.Pd., M.Si.)

kesimpulan bahwa penggunaan media handphone dalam pembelajaran IPS dengan materi organisasi pergerakan dan tumbuhnya semangat kebangsaan dapat meningkatan perhatian dan minat siswa dalam pembelajaran IPS yang sedang dilaksanakan sehingga dapat memotivasi siswa untuk lebih aktif melibatkan diri selama berlangsungnya proses pembelajaran IPS, dapat meningkatkan pemahaman dan kemampuan siswa dalam mengerjakan tugas dan menjawab soalsoal setelah pembelajaran IPS disampaikan dan dijelaskan dengan menggunakan media handphone. Pada penelitian siklus I nilai rerata yang didapat siswa adalah 73,50 dan pada penelitian siklus II nilai rerata sudah mencapai 82,50, hal ini berarti setelah pembelajaran IPS dengan materi materi organisasi pergerakan dan tumbuhnya semangat kebangsaan menggunakan media handphone terjadi peningkatan minat belajar siswa.

\section{B. Saran}

Berdasarkan kesimpulan yang telah diperoleh maka dapat disampaikan beberapa saran sebagai berikut :

1. Kepada Kepala Sekolah

a. Lebih memperhatikan sarana dan prasarana yang menunjang pembelajaran baik di kelas maupun di luar kelas.

b. Hendaknya lebih menekankan pada guru untuk menggunakan media pembelajaran yang tepat, mudah dan murah untuk kelancaran proses belajar mengajar sehingga dapat meningkatkan mutu pendidikan.

2. Kepada Guru

a. Diharapkan dalam suatu pembelajaran dapat menggunakan media yang tepat demi mendukung kelancaran pembelajaran

b. Diharapkan kepada guru agar dapat lebih banyak menggunakan media HP/ handpone pada pembelajaran IPS agar siswa lebih berminat belajar IPS.

\section{DAFTAR PUSTAKA}

Arif Sardiman. 2004. Interaksi dan Motivasi Belajar Mengajar. Jakarta Raja Grasindo Persada.

Azhar Arsyad.2011. Media Pembelajaran. Jakarta: PT Rajawali Press. 
Crow, L.D., dan Crow, A. 1982. Psikologi Pendidikan, penerj. Kasijan Z,. Surabaya: PT Bina Ilmu.

Dailer dalam Sumartono. 1983. Modifikasi Kegiatan Belajar Mengajar. Bandung Tarsito.

Dimiyati dan Mudjiono. 2006. Belajar Dan Pembelajaran. Jakarta. Rineka Cipta. Djamarah dan Zain.2008. Psikologi Belajar. Jakarta: Rineka Cipta.

Hamalik.2004. Kurikulum dan Pembelajaran. PT. Bumi Aksara.

Mohamad Arbin Samsudin, 2005. Psikologi Pendidikan. Jakarta PT.Rosdakarya.

Purbakawaca dalam Nurkancana, 1987. Kurikulum dan Pembelajaran. Jakarta Rineka Cipta.

Rahadi Aristo. Media Pembelajaran. Direktorat Jendral Pendidikan Dasar.Jakarta. Uno. Dkk. 2004. Model Pembelajaran. Nurul Jannah Gorontalo.

Usman Basirudin. 2002. Metode Pembelajaran. Ciputat Press. Jakarta. 